\title{
A NOVEL KV1.1 POTASSIUM CHANNEL BLOCKING TOXIN FROM THE VENOM OF Palamneus gravimanus (INDIAN BLACK SCORPION)
}

\author{
MORE S. S. (1), MIRAJKAR K. K. (1), GADAG J. R. (1), MENON K. S. (2), \\ MATHEW M. K. (2)
}

(1) Research Laboratory, Department of Biochemistry, Toxinology Division, Karnataka University, Dharwad, Karnataka, India; (2) National Centre for Biological Sciences, Tata Institute of Fundamental Research, UAS-GKVK, Bangalore, Karnataka, India.

ABSTRACT: A peptide toxin was isolated from the venom of Palamneus gravimanus, the Indian black scorpion, to block human Kv1.1 channels expressed in Xenopus laevis oocytes. A $4.5 \mathrm{kD}$ peptide (toxin), as confirmed by SDS-PAGE, was purified to homogeneity by ion exchange chromatography using CM-Sephadex C-25 followed by Sephadex G-50 gel filtration. Palamneus gravimanus toxin (PGT) selectively blocks the human cloned voltage-gated potassium channel hKv1.1 in a two-electrode voltage-clamp (TEVC) technique. The results obtained indicate that the toxin blocks the hKv1.1 channel at a nanomolar concentration range $\left(\mathrm{K}_{\mathrm{i}}\right.$ value of 10 $\mathrm{nM}$ ) of the peptide to the external side of the cell. The blockage seems to be voltagedependent. Comparative structure of PGT (a $4.5 \mathrm{kD}$ peptide) with BTK-2 suggests a close relationship; therefore this toxin can be employed to investigate the hKv1.1 channel structure.

KEY WORDS: hKv1.1, $\mathrm{K}^{+}$channel, PGT, TEVC, Palamneus gravimanus, Xenopus laevis oocytes, Indian black scorpion.

CORRESPONDENCE TO: J. R. GADAG, Department of Biochemistry, Toxinology Division, Karnataka University, 580003, Dharwad, Karnataka, India.

Email: sunilacr@yahoo.co.in 


\section{INTRODUCTION}

Many toxins have been isolated from snake and scorpion venoms. Scorpion venoms contain several toxins, which are proved to be high-affinity ligands of ion channels making them useful as pharmacological probes (7). Two main groups of scorpion toxins have been distinguished based on their pharmacological properties. They either modulate the activity of $\mathrm{Na}^{+}$channels excitable cells or specifically block $\mathrm{K}^{+}$ channels (14). This classification, based on their pharmacological action, also agrees well with the structural properties of this peptide family, since toxins active against $\mathrm{Na}^{+}$channels are made up of a polypeptide chain of 60-80 amino acid residues reticulated by four disulfide bridges, versus the 30-40 amino acids and three to four disulfide bridges of those active against $\mathrm{K}^{+}$channels.

Potassium channels are present in all cells and are known to regulate the cell membrane potential. They are particularly important in neuronal cells, where they regulate the repolarization phase of the action potential dependent excitability of the neuron. If the potassium channels are blocked by drugs, the action potential tends to be prolonged, and if this happens at a nerve terminal it results in a prolonged depolarization, allowing calcium channels to remain open for a longer period and cause a greater release of the neurotransmitter substance.

In order to study the role of potassium channels and their subtypes in physiology, it is helpful to have biological tools that interfere with the channel activity. Small molecules like 3.4-diaminopyridine and tetraethyl ammonium, though known to block potassium channels, are not very specific and potent for particular subtypes of channels (9). The most useful tools for studying the potassium channel physiology are naturally occurring small peptides isolated from different scorpion venoms. Hence, studying the physiology and pharmacology of $\mathrm{K}^{+}$channels by using scorpion toxin probes has gained importance in structural biology and neuropharmacology.

We have purified a novel peptide toxin (PGT) from the venom of the Indian black scorpion Palamneus gravimanus. An attempt has been made to characterize this peptide toxin regarding its molecular weight, $\mathrm{LD}_{50}$, and electrophysiological action on hKv1.1 potassium channel. PGT isolated from $P$. gravimanus showed its highest homology to BTK-2, a $3.5 \mathrm{kD}$ peptide isolated from Buthus tamulus (Indian red scorpion), in general, and its specificity towards inhibition of the hKv1.1 channel, in particular. 


\section{MATERIALS AND METHODS}

\section{Materials}

Palamneus gravimanus lyophilized crude venom was obtained from the Haffkine Institute, Parel, Mumbai, India. CM-Sephadex C-25 column gel (Pharmacia, Sweden) and Sephadex G-50 (Sigma Chemicals, USA) were used. Bovine serum albumin (BSA), used as a standard for protein assay, was obtained from Himedia, Mumbai, India. The chemicals used for buffer preparation were of analytical grade. We also utilized UV-Visible spectrophotometer from Elico (India); acrylamide; bisacrylamide; sodium dodecyl sulphate; Bromophenol Blue; Coomassie Brilliant Blue R-250 (Himedia, Mumbai); TEMED (N,N,N',N'-tetramethylethylenediamine); and broad range molecular weight markers PMW-B (Bangalore, Genei, India).

\section{Purification}

Lyophilized crude venom of Palamneus gravimanus was weighed (100 mg), dissolved in $20 \mathrm{ml}$ of water and stirred at $4^{\circ} \mathrm{C}$ for $4 \mathrm{~h}$. This was next centrifuged at $10,000 \mathrm{~g}$ at $4^{\circ} \mathrm{C}$ for $20 \mathrm{~min}$ to separate the mucous from the venom. The clear supernatant was separated and the pellet was resuspended in $20 \mathrm{ml}$ of water, stirred for $4 \mathrm{~h}$, and centrifuged; the supernatant was pooled and filtered in a $0.2 \mu \mathrm{m}$ filter and then lyophilized on a Hindvac speed lyophilizer.

The processed and lyophilized crude venom was fractionated on a CM-Sephadex C25 column by the method of Ramachandran et al. (15). Palamneus gravimanus venom (100 mg) dissolved in $5 \mathrm{ml}$ of $0.05 \mathrm{M}$ Tris-HCl buffer, $\mathrm{pH} 8.5$, was loaded on a previously equilibrated CM-Sephadex C-25 column $(1.5 \times 18 \mathrm{~cm})$. After washing the column with $500 \mathrm{ml}$ of $0.05 \mathrm{M}$ Tris- $\mathrm{HCl}$ buffer $(\mathrm{pH} 8.5)$, the venom components were eluted using Tris- $\mathrm{HCl}$ buffer, $\mathrm{pH} 8.5$, with a linear gradient of $250 \mathrm{ml}$ 0-0.5 M NaCl at a flow rate of $40 \mathrm{ml} / \mathrm{h}$ and $4 \mathrm{ml}$ fractions were collected. Protein elution profile was monitored at $280 \mathrm{~nm}$ on a UV-Visible spectrophotometer. Fractions showing the highest toxicity towards white mice were pooled, dialyzed, and lyophilized.

\section{Gel filtration on Sephadex G-50}

Fractions showing toxicity towards white mice were pooled, dialyzed, lyophilized, subsequently subjected to gel filtration on a Sephadex G-50 column $(1.5 \times 60 \mathrm{~cm})$, and eluted with $0.01 \mathrm{M}$ Tris- $\mathrm{HCl}$ buffer $(\mathrm{pH} 8.5)$. The protein was eluted at a flow rate of $12 \mathrm{ml} / \mathrm{h}$. Fractions of $3 \mathrm{ml}$ were collected and the elution was monitored at $280 \mathrm{~nm}$ 
on a UV-spectrophotometer. The highest toxic protein peak eluted from the column was pooled, dialyzed, lyophilized and then subjected to SDS-PAGE to confirm its homogeneity, molecular weight, $\mathrm{LD}_{50}$, and potassium $\left(\mathrm{K}^{+}\right)$channel activity.

Protein concentrations were determined by measuring their absorbance at $280 \mathrm{~nm}$ by the method of Lowry et al. (12), using bovine serum albumin as standard.

\section{Molecular weight determination by gel filtration chromatography}

The molecular weight of the isolated toxin was estimated by gel filtration chromatography, according to the method of Andrews (2), on Sephadex G-75 calibrated columns, using 0.05 M Tris- $\mathrm{HCl}$ buffer ( $\mathrm{pH} 8.5)$.

Sephadex G-75 was suspended in 0.05 M Tris-HCl buffer $(\mathrm{pH} 8.5)$ containing 100 $\mathrm{mM} \mathrm{NaCl}$ and allowed to swell for 24 hours. Fine particles were then removed by decanting the supernatant, and the swollen gel was deaerated overnight in a vacuum desiccator. The gel was packed in a column $(1.5 \times 60 \mathrm{~cm})$ and equilibrated with the same buffer. The flow rate was adjusted at $12 \mathrm{ml} / \mathrm{h}$ using a peristaltic pump. Void volume $\left(\mathrm{V}_{\mathrm{o}}\right)$ of the column was determined by using Blue Dextran $(2 \mathrm{mg} / \mathrm{ml}$ in an equilibration buffer containing 3\% sucrose). The column was calibrated with standard molecular weight markers. Each standard protein $(2 \mathrm{mg} / \mathrm{ml})$ of the buffer (containing $3 \%$ sucrose) was layered on the gel. The elution was carried out with the same buffer at a constant flow rate of $12 \mathrm{ml} / \mathrm{h}$. Fractions of $3 \mathrm{ml}$ were collected and the protein elution was monitored by determining the absorbance at $280 \mathrm{~nm}$ using a Hitachi 15020 spectrophotometer. The total volume of the eluent up to the fraction having maximum absorbance was considered as the elution volume of the protein $\left(\mathrm{V}_{\mathrm{e}}\right)$. The elution volumes of different standard proteins of known molecular weights and the purified toxin were determined under similar conditions.

A calibration curve was obtained by plotting $V_{\mathrm{e}} / \mathrm{V}_{0}$ against their respective logarithmic molecular weights. Insulin, aprotinin, lysozyme, chymotrypsinogen A, carbonic anhydrase, ovalbumin, and bovine serum albumin were used as standard proteins to obtain the calibration curve. From this calibration curve, the molecular weight of the purified toxin was determined. 
Molecular weight determination by the sodium dodecyl sulphate polyacrylamide gel electrophoresis

The molecular weight was determined on SDS-PAGE, according to the method of Laemmli (10).

Molecular weight markers, the crude venom, and the toxin samples after each purification step were subjected to 6-16\% gradient SDS-Polyacrylamide gel electrophoresis at $\mathrm{pH} 6.8$ using Tris- $\mathrm{HCl}$ buffer, stained with Coomassie Brilliant Blue R-250 for 2 hours and subsequently distained overnight with methanol:acetic acid:water (30:10:60 v/v).

The migration distances of the individual bands of the standard proteins, toxin samples, and those of the tracking dye from the origin of the separating gel were measured. Relative mobility $\left(R_{f}\right)$ of the individual proteins was determined by the help of equation.

A calibration curve was obtained by plotting the relative mobility values $\left(R_{f}\right)$ of standard proteins against logarithms of their molecular weights. The molecular weight of the toxin was calculated from this calibration curve.

\section{Toxicity studies}

Albino mice (Mus musculus, 20-40 g body weight, 10 months old), crude venom, Palamneus gravimanus purified toxin, and saline $(0.9 \% \mathrm{NaCl})$ were used in the toxicity studies performed according to the method of Reed and Meunch (16).

Mice that had fasted the previous night were used in the present study. Three groups, each comprised of six animals were treated as follows: Group 1: saline control group; Group 2: purified toxin; Group 3: crude venom.

The control group received $4 \mathrm{ml}$ of saline. Whereas varying doses of purified fraction and crude venom were intraperitoneally injected into the other groups. All the animals were observed for $48 \mathrm{~h}$.

\section{Activity of purified toxic peptide on potassium channels}

In the present investigation, $\mathrm{K}^{+}$channel activity of the scorpion purified toxin was determined according to the method of Ritu Dhawan et al. (4). 


\section{Isolation and maintenance of Xenopus oocytes}

Adult female frogs (Xenopus laevis) were acquired from Xenopus Express (Plant City, FL, USA), and their colony was maintained in a temperature-controlled room $\left(20^{\circ} \mathrm{C}\right)$ with 12 hours of light and dark cycle.

Oocytes were isolated by mini-laparotomy from adult female Xenopus laevis. The frogs were anesthetized by immersion in $0.04 \%$ benzocaine (Sigma Chemicals, USA) for 15-20 min and then placed on a wet platform during dissection and removal of the ovarian lobes. The incision was sutured and closed, and the frog was allowed to recover for about two months before removal of another batch of oocytes. Ovarian lobes were manually divided into smaller clusters of oocytes and were subsequently treated with $1 \mathrm{mg} / \mathrm{ml}$ type $1 \mathrm{~A}$ collagenase (Sigma Chemicals, USA) in OR-Mg solution (82 $\mathrm{mM} \mathrm{NaCl}, 2 \mathrm{mM} \mathrm{KCl}$, and $5 \mathrm{mM}$ HEPES [pH 7.7]). The isolated stage $\mathrm{V}$ and $\mathrm{VI}$ oocytes were then incubated for microinjection at $18^{\circ} \mathrm{C}$ in a $\mathrm{ND}(96 \mathrm{mM})-\mathrm{HS}$ solution (96 mM NaCl, $2 \mathrm{mM} \mathrm{KCl}, 1.8 \mathrm{mM} \mathrm{CaCl}_{2}, 1 \mathrm{mM} \mathrm{MgCl}$, $5 \mathrm{mM}$ HEPES, 2.5 mM Na-Pyruvate [pH 7.7]), supplemented with $100 \mathrm{U} / \mathrm{ml}$ of Penicillin-Streptomycin solution (Sigma chemicals USA) and 5\% heat inactivated horse serum.

\section{Potassium channel expression in Xenopus oocytes}

In the present investigation the human cloned voltage-gated potassium channel hKv1.1 was expressed in Xenopus laevis oocytes by the method of Baumann et al. (3)

Kv1.1 channel was present in a pGEM-3Z vector (Promega) modified to contain untranslated sequences of Xenopus $\beta$-globulin gene to enhance expression in oocytes (11). Kv1.1 channel had a single amino acid difference (Ser 357 ALA) when compared to the published sequence of the native channel. RNA transcription using T7 polymerase and Xenopus oocyte injections were carried out using the protocols previously described by MacKinnon et al. (13).

\section{Microinjection}

The stock solution (> $1 \mathrm{mg} / \mathrm{ml}$ ) of $\mathrm{cRNA}$ was diluted to $150-300 \mathrm{mg} / \mathrm{ml}$ concentrations in diethyl pyrocarbonate (DEPC) treated water. Then, $46 \mathrm{ml}$ of this cRNA solution was microinjected into each oocyte, using a Nanojet automated oocyte injector (Drummond Scientific, Broomall, PA, USA) containing a glass microcapillary with a terminal diameter of 10-15 $\AA$. The injected oocytes were maintained in ND96-HS 
solution at $18^{\circ} \mathrm{C}$, and electrophysiological recordings were determined 2-7 days after the injection.

\section{Electrophysiology}

Xenopus oocytes expressing $\mathrm{K}^{+}$channels were voltage-clamped by using a twoelectrode voltage-clamp electrophysiology rig. OC-725 oocyte clamp amplifier (Warner Instruments, Hamden, CT, USA) was utilized to maintain the holding potentials and record membrane currents. The microelectrodes that were pulled by using a P-97 micropipette puller (Sutter Instruments, Novato, CA, USA) were filled with $3 \mathrm{M} \mathrm{KCl}$ and had an initial tip resistance of 0.4 to $1.5 \mathrm{MW}$. The external recording solution was modified ND96 (96 mM sodium gluconate, $2 \mathrm{mM}$ potassium gluconate, $1.8 \mathrm{mM}$ calcium gluconate, $1 \mathrm{mM}$ magnesium gluconate, and $5 \mathrm{mM}$ HEPES [pH 7.7]). Solution exchange was achieved by gravity flow. Analogue data from the amplifier was sampled at 5-25 kHz and filtered at 2-10 kHz in a low pass filter (LPF-100, Warner Instruments), digitized by a TL-1 series of digitizers (Axon Instruments). A software package was used to generate voltage-clamp commands, obtain membrane current, and analyze digitized data. All electrophysiological experiments were performed at room temperature

\section{RESULTS}

\section{CM-Sephadex C-25 column chromatography}

Palamneus gravimanus crude venom was resolved into four bound and one unbound protein peak on a CM-Sephadex C-25 column (Figure 1). Fractions number 70-95, which showed maximum toxicity to white mice, were pooled, lyophilized, subjected to gel filtration on Sephadex G-50 column, and fractionated into three peaks. Peak II (Figure 2) had the highest protein concentration and toxicity. The summary of the purification procedure is given in Table 1.

\section{Criteria for purity and molecular weight determination}

Sephadex G-50 purified toxin was homogeneous on SDS-PAGE, as shown in Figure 3.

The molecular weight of the toxin was determined by SDS-PAGE and gel filtration on Sephadex G-75 using standard protein molecular weight markers (Figures 4 and 5). It was about $4.5 \pm 0.1 \mathrm{kD}$. 


\section{Toxicity Studies}

Intravenous administration of Palamneus gravimanus purified toxin produced typical hypertensive symptoms and showed a $L D_{50}$ value of $2 \mathrm{mg} / \mathrm{kg}$ mouse. Group 1 (control group) was administered saline. Dosage of the purified toxin was calculated on the basis of total protein content. Palamneus gravimanus crude venom showed a $\mathrm{LD}_{50}$ value of $800 \mu \mathrm{g} / \mathrm{kg}$ mice, which died with typical neurotoxic symptoms.

\section{Purified toxin activity on human cloned potassium channel (hKv1.1)}

Potassium channels are one of the most important molecular targets of scorpion toxins. The reaction of an isolated peptide toxin on human cloned potassium channels was determined using Xenopus laevis oocyte system for homologous channel expression and a standard two-electrode voltage-clamp set up for $\mathrm{K}^{+}$current recording. hKv1.1 was voltage-clamped at +20 to $-70 \mathrm{mV}$ and stopped to a range of test potentials.

Application of Palamneus gravimanus venom toxin to these oocytes resulted in the reduction of hKv1.1 currents. Figure 6a shows control oocytes before addition of purified venom toxin at $+10 \mathrm{mV}$; the maximum current observed was $1098 \mathrm{nA}$. While for the same oocyte, after addition of $10 \mathrm{nM}$ purified venom toxin and after 30 minutes, the same maximum current at $+10 \mathrm{mV}$ was now reduced to $523 \mathrm{nA}$, which was almost a $50 \%$ reduction in the current (Figure 6b).

In figure 6c, the graph shows the voltage-dependence of channel blocking by Palamneus gravimanus venom toxin. The same concentration of toxin was used for this assay and was tested at different membrane potentials after a gap of 4 minutes for the toxin to act. A "relative channel blocking" of $0.95 \%$ was observed at $-20 \mathrm{mV}$. The graph in Figure $6 \mathrm{~d}$ shows channel blocking as a function of the Palamneus gravimanus toxin concentration. Relative channel blockage is calculated by dividing the current produced in the presence of toxin by the control current (i.e. the current produced in the absence of the toxin). The results obtained indicate that the toxin blocks hKv1.1 channel in a nanomolar concentration range (10 nM). The block probably seems to be voltage-dependent as indicated by the graph (Figure 6e).

In Figure 6f, the graph shows the effect of Palamneus gravimanus toxin at a given concentration $(20 \mathrm{nM})$ at a single potential of $+20 \mathrm{mV}$ at different time intervals (timedependent toxin action). 
Table 1: Summary of the purification of toxins from scorpion (Palamneus gravimanus) crude venom

\begin{tabular}{c|c|c|c}
\hline No. & Purification steps & Amount of protein * $(\mathrm{mg})$ & Protein recovery (\%) \\
\hline 1 & Crude venom (100 mg) & 85 & 100 \\
2 & CM-Sephadex C-25 & 36 & 42.3 \\
3 & Sephadex G-50 & 11.5 & 31.9 \\
\hline
\end{tabular}

*Protein concentration was assayed by the method of Lowry et al. (1951)(12).

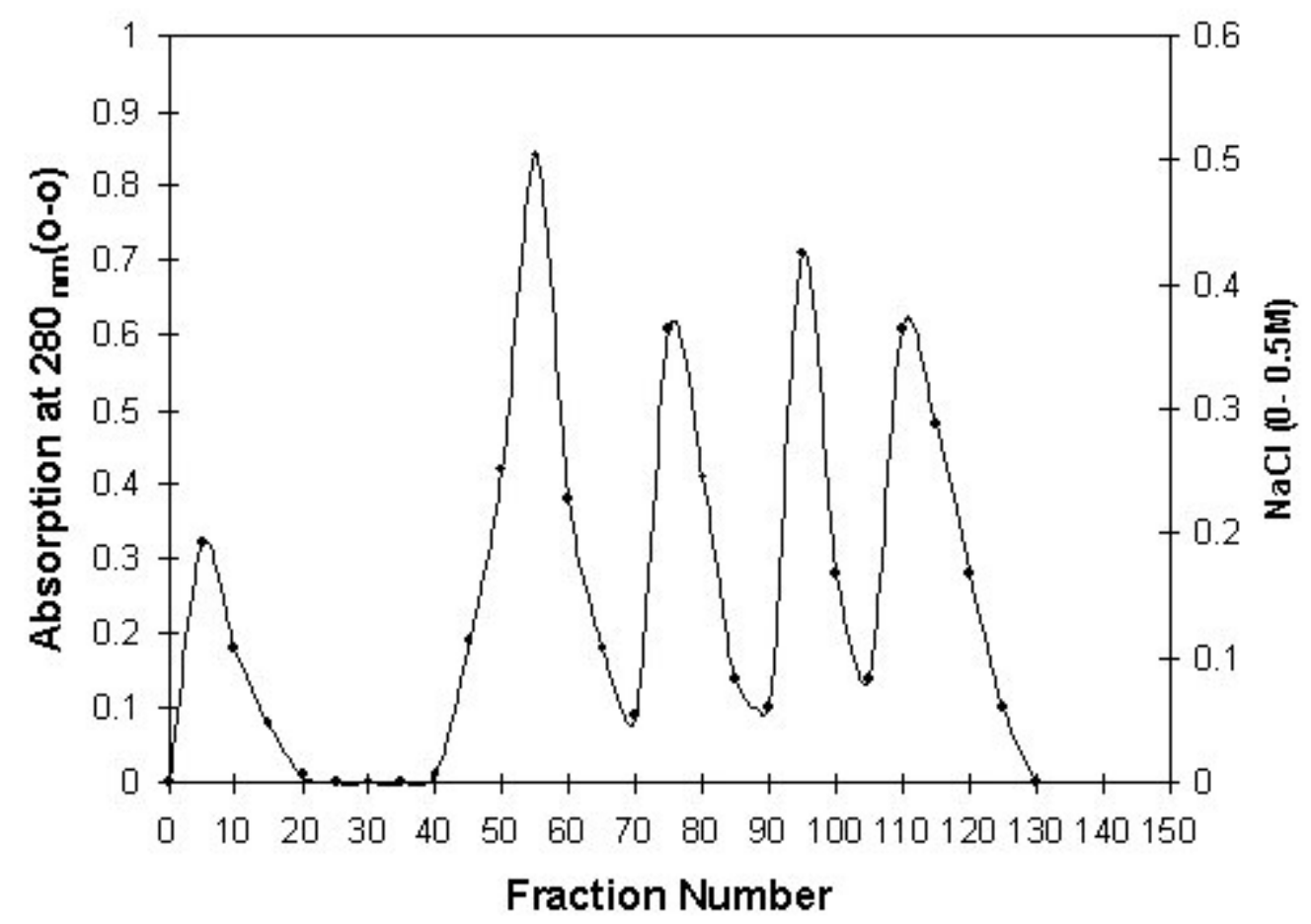

Figure 1: CM-Sephadex C-25 column chromatography of Palamneus gravimanus venom. The crude venom was dissolved in $5 \mathrm{ml}$ of $0.05 \mathrm{M}$ Tris- $\mathrm{HCl}$ buffer, $\mathrm{pH} 8.5$, and loaded on a previously equilibrated CM-Sephadex C-25 column $(1.5 \times 18 \mathrm{~cm})$. After washing the column with $500 \mathrm{ml}$ of the Tris- $\mathrm{HCl}$ buffer, $\mathrm{pH} 8.5$, the venom components were eluted using Tris- $\mathrm{HCl}$ with a linear gradient of $250 \mathrm{ml}$ 0-0.5 M NaCl at a flow rate of $40 \mathrm{ml} / \mathrm{h}$, and $4.0 \mathrm{ml}$ fractions were collected. Proteins of the fractions were monitored at $280 \mathrm{~nm}$. 


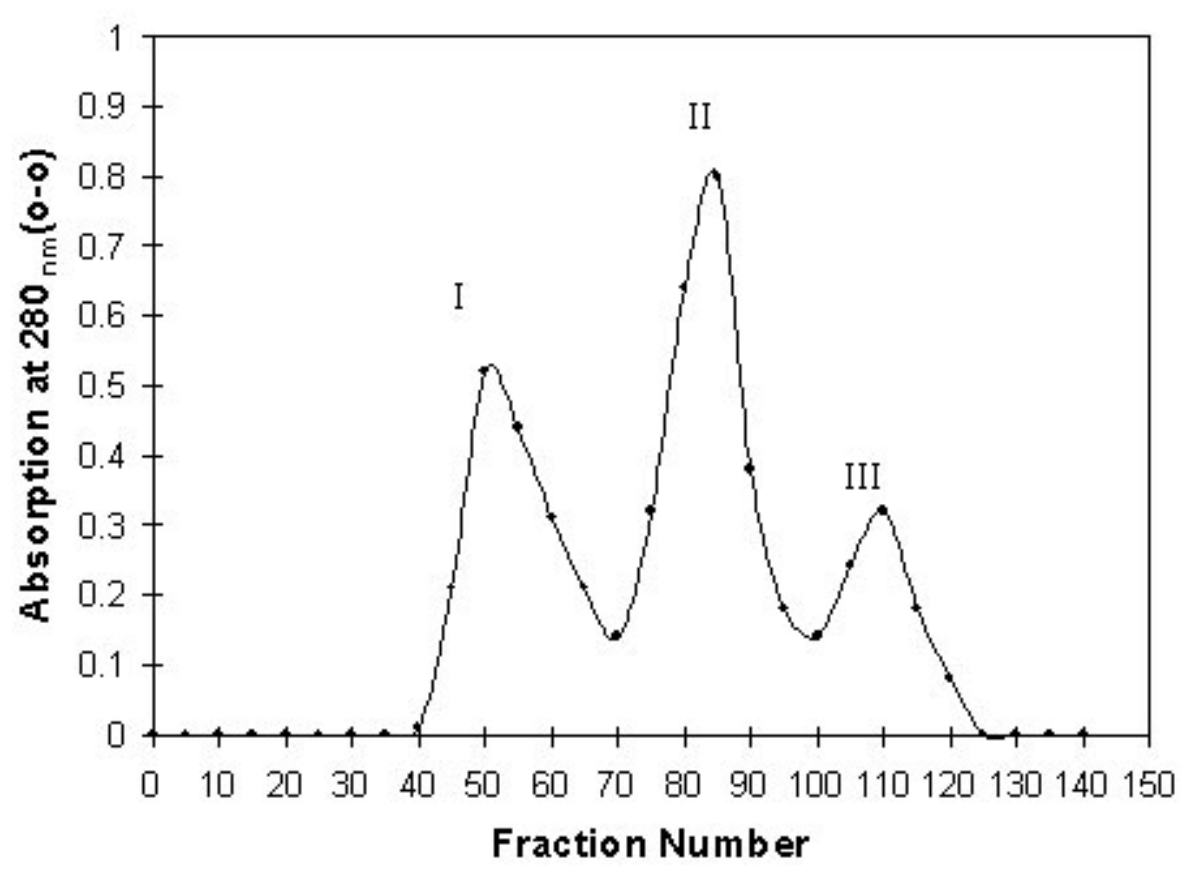

Figure 2: Gel filtration chromatography of Peak-III from Figure 3 (Lane D) on a Sephadex G-50 column $(1.5 \times 60 \mathrm{~cm})$. Fractions were eluted with $0.01 \mathrm{M}$ Tris- $\mathrm{HCl}$, $\mathrm{pH} 8.5$, at a flow rate of $12 \mathrm{ml} / \mathrm{h}$, and those fractions of $3.0 \mathrm{ml}$ were collected. 


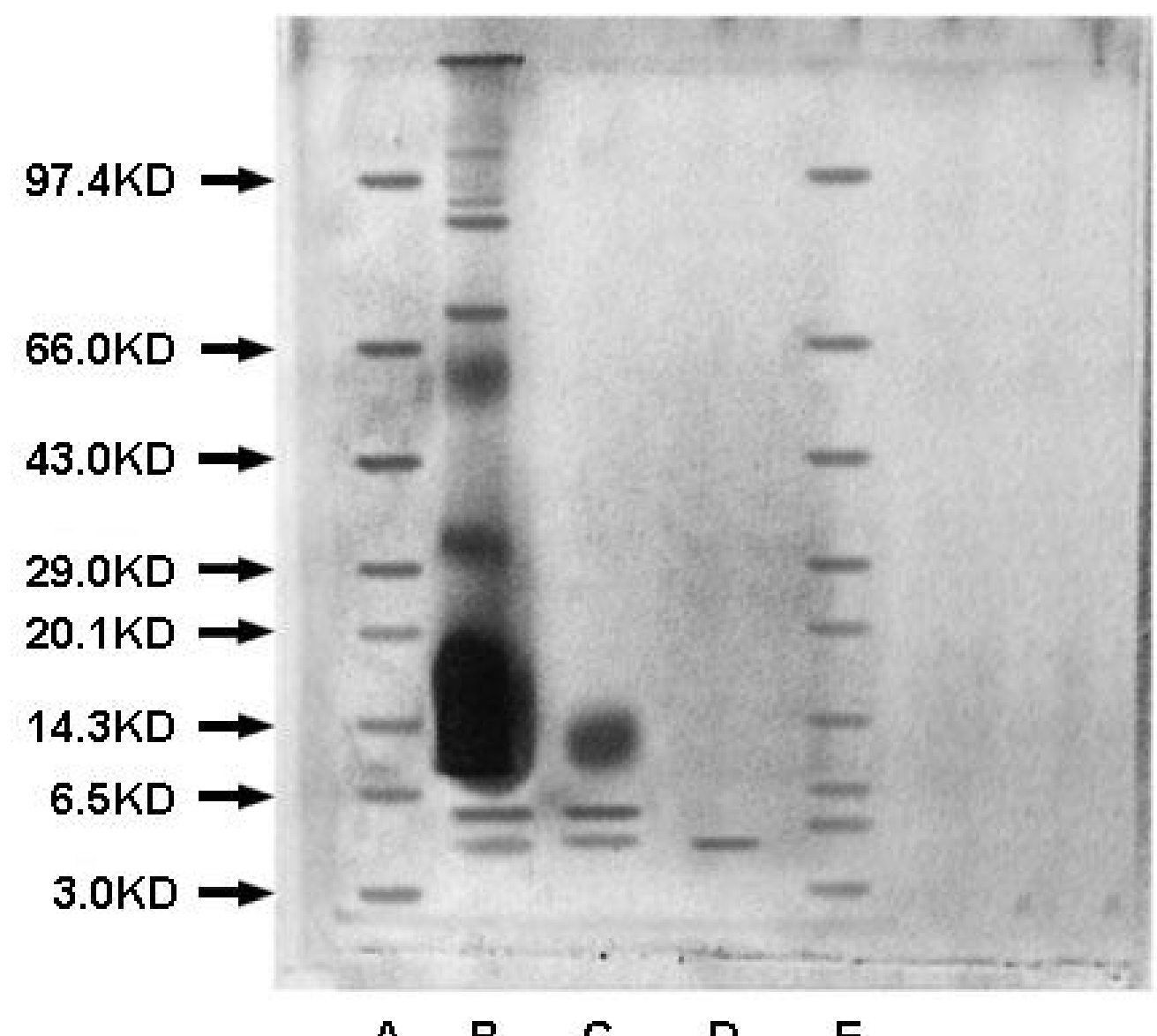

A $\quad$ B $\quad$ C $\quad$ D $\quad$ E

Figure 3: SDS-PAGE of the purified Palamneus gravimanus toxin. Lane A: molecular weight markers; Lane B: Palamneus gravimanus crude venom; Lane C: purified toxin after CM-Sephadex C-25 column; Lane D: purified toxin after Sephadex G-50; Lane $\mathrm{E}:$ molecular weight markers. 


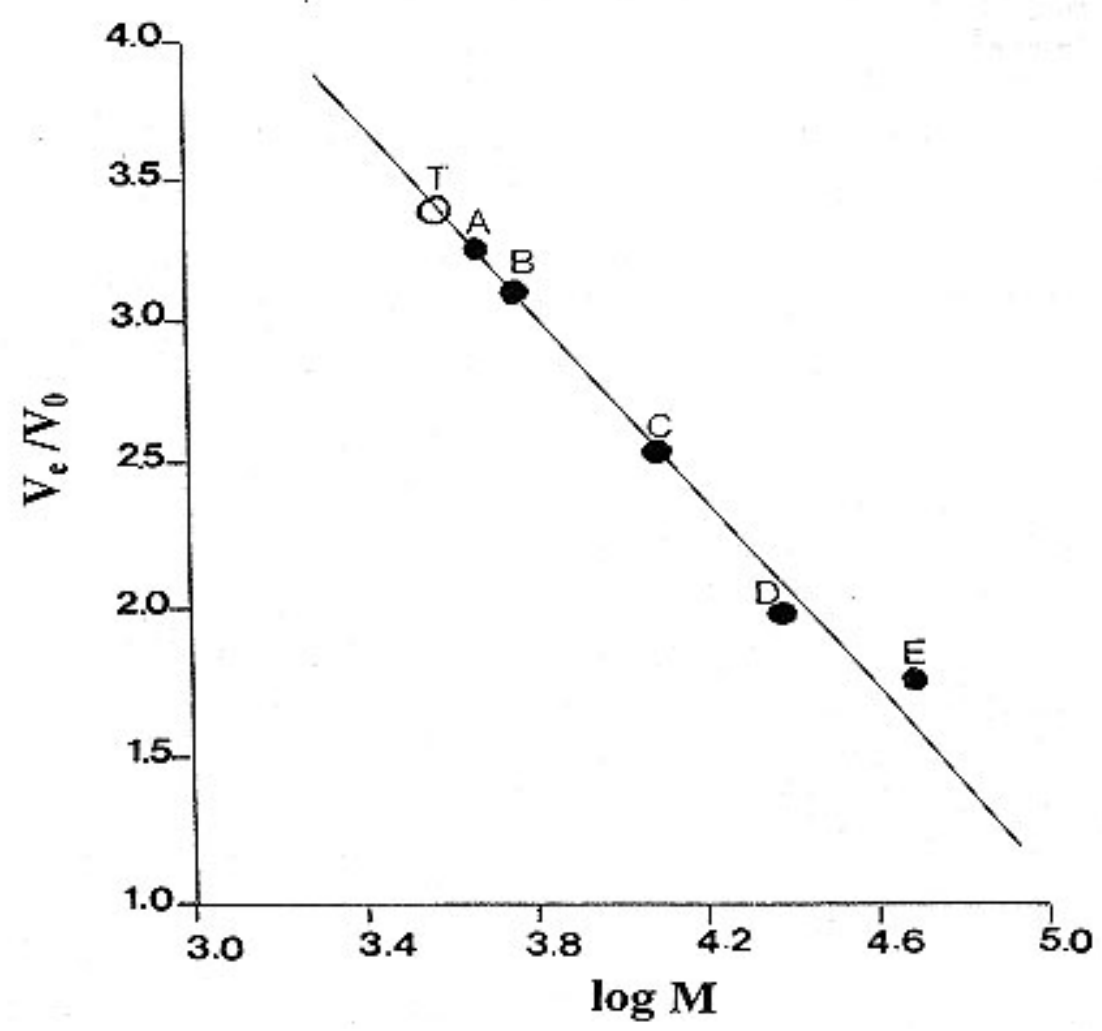

Figure 4: Calibration curve for the determination of the toxin molecular weight at $\mathrm{pH}$ 8.5 by gel filtration chromatography on Sephadex G-75. Marker proteins used for calibration: A: insulin (5,600); B: aprotinin (6,500); C: lysozyme (14,300); D: carbonic anhydrase $(29,000)$; E: ovalbumin $(45,000)$; T: toxin. 


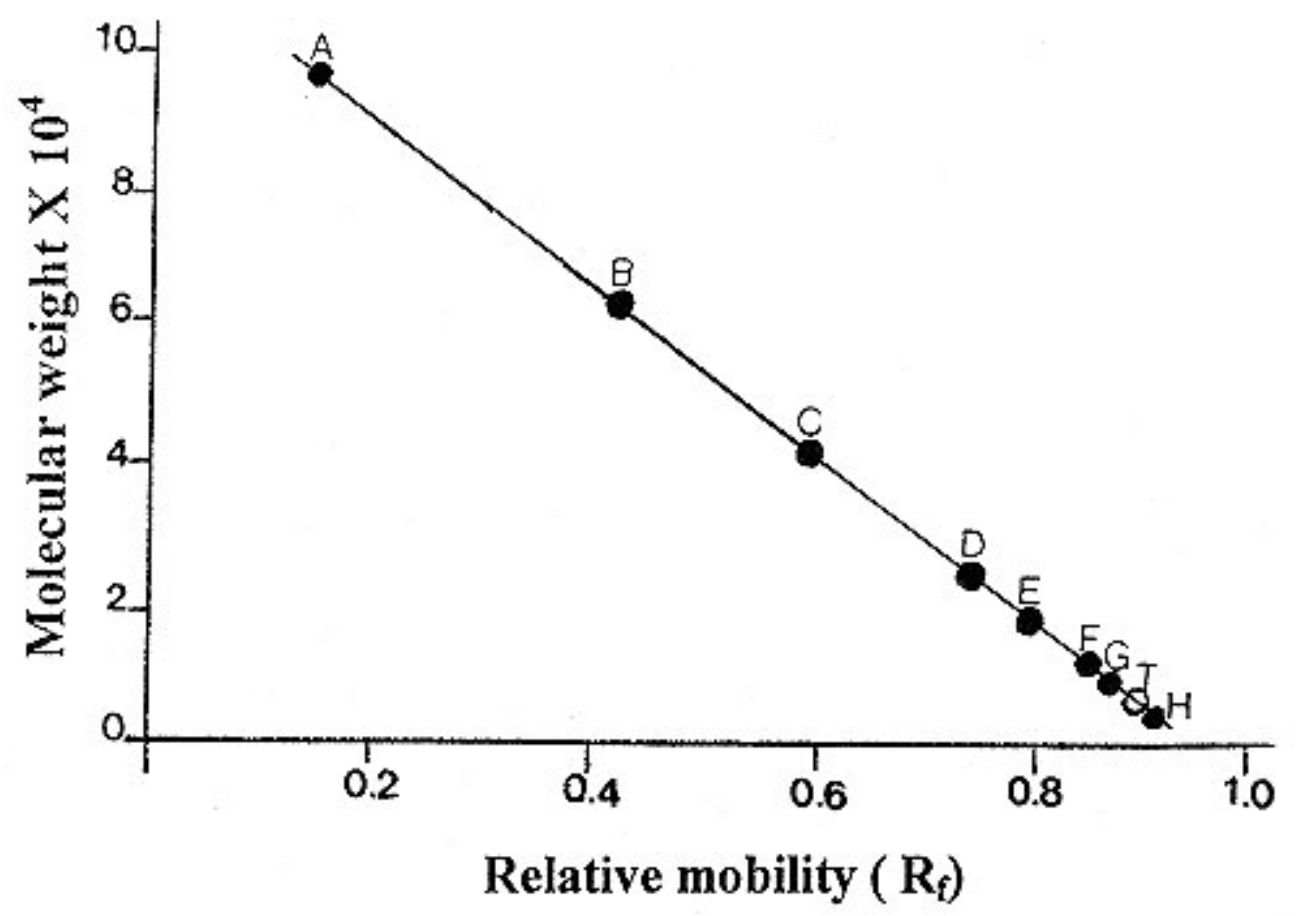

Figure 5: Calibration curve for the determination of the toxin molecular weight by SDS-PAGE (6-16\%). Marker proteins used for calibration: A: Phosphorylase b $(97,400)$; B: bovine serum albumin $(66,000)$; C: ovalbumin $(43,000)$; D: carbonic anhydrase (29,000); E: soyabean trypsin inhibitor (20,100); F: lysozyme $(14,300)$; G: aprotinin (6,500); H: insulin; T: toxin. 


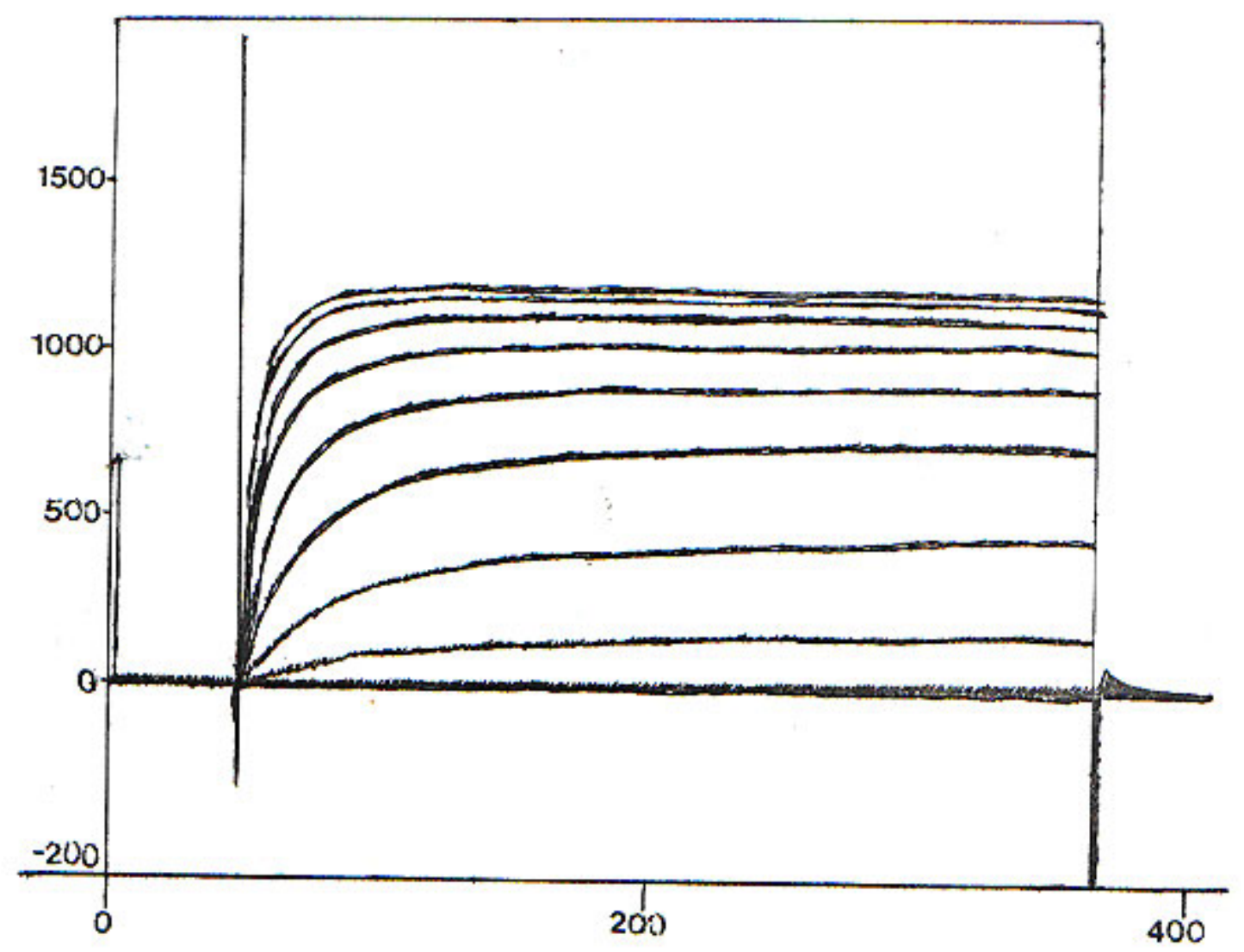

Figure 6a: Control oocytes before the addition of Palamneus gravimanus toxin at +10 $\mathrm{mV}$ (the maximum current is $1098 \mathrm{nA}$ ). 


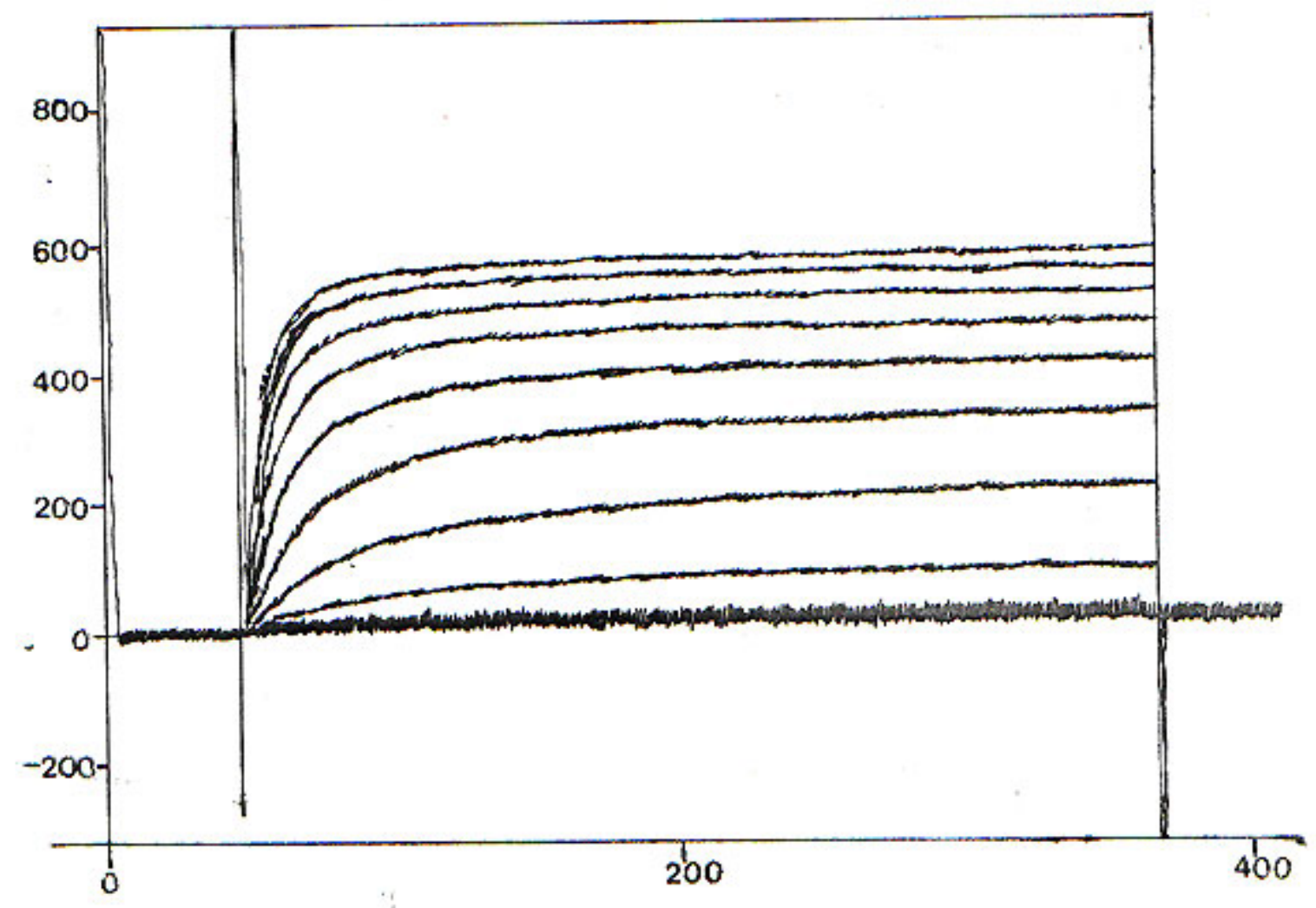

Figure 6b: The same oocyte after the addition of $20 \mathrm{nM}$ Palamneus gravimanus toxin. After $30 \mathrm{~min}$, the maximum current at $+10 \mathrm{mV}$ reduced to $523 \mathrm{nA}$.

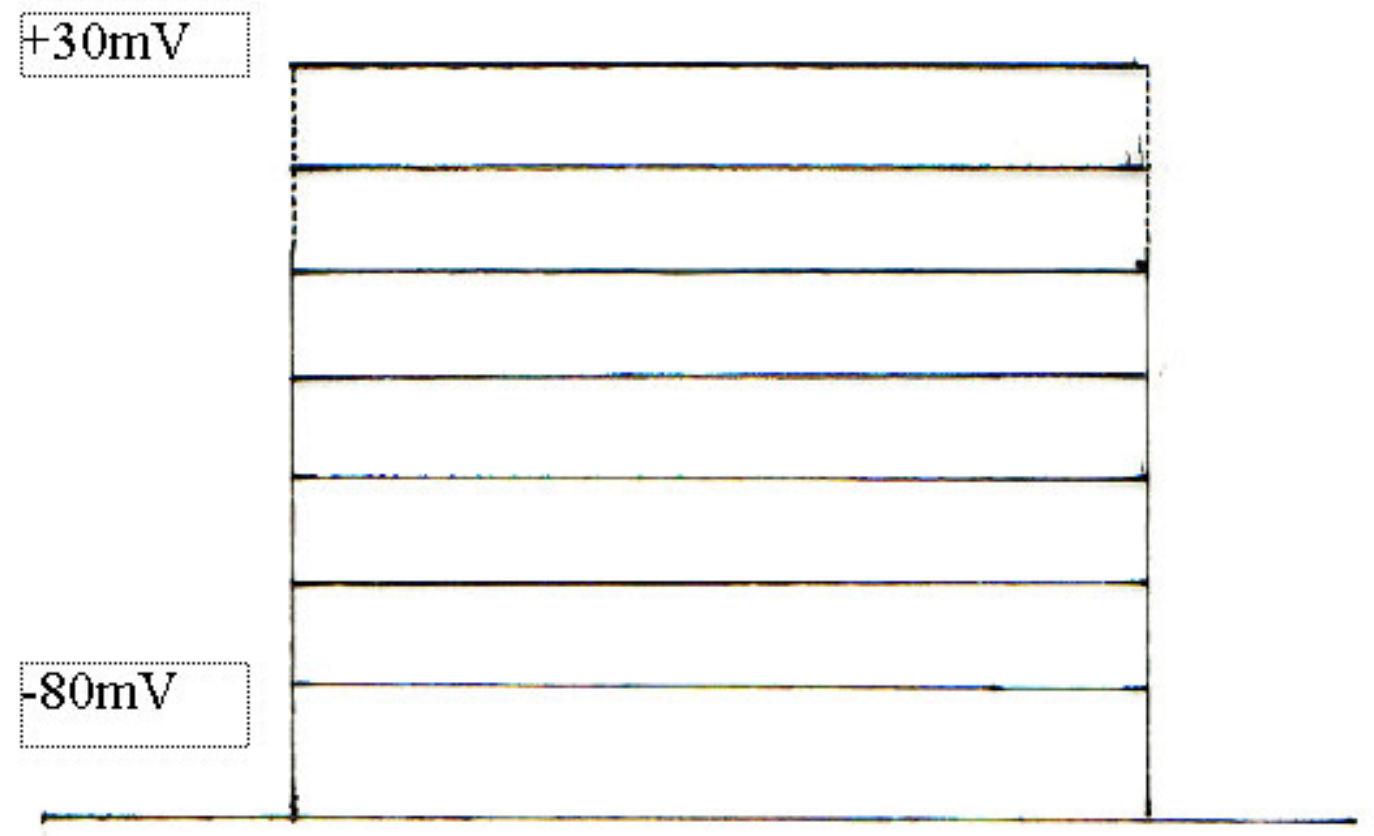

Figure 6c: Pulse protocol used for the measurement of currents. 


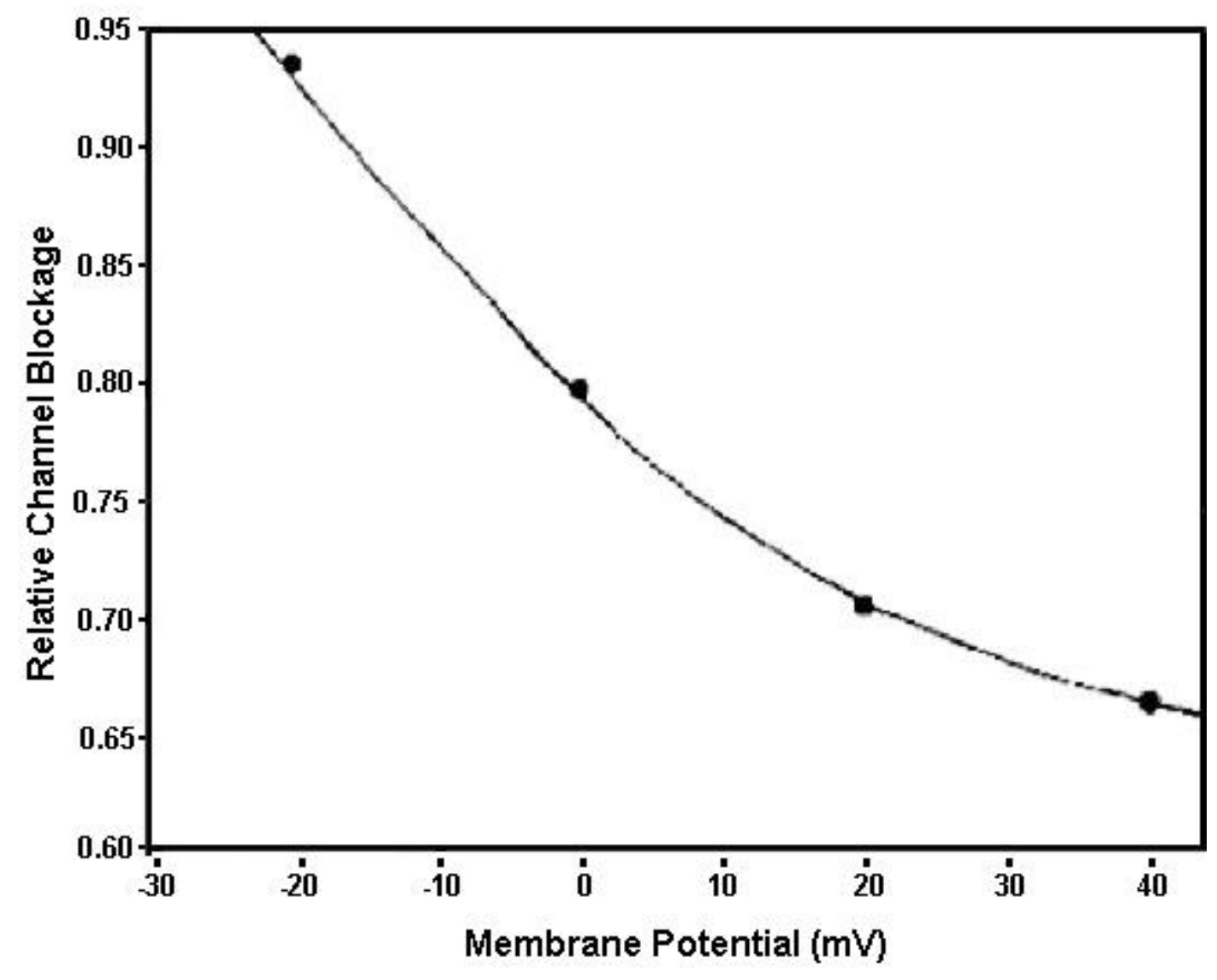

Figure 6d: Voltage-dependence of the channel blocking by $P$. gravimanus toxin. 


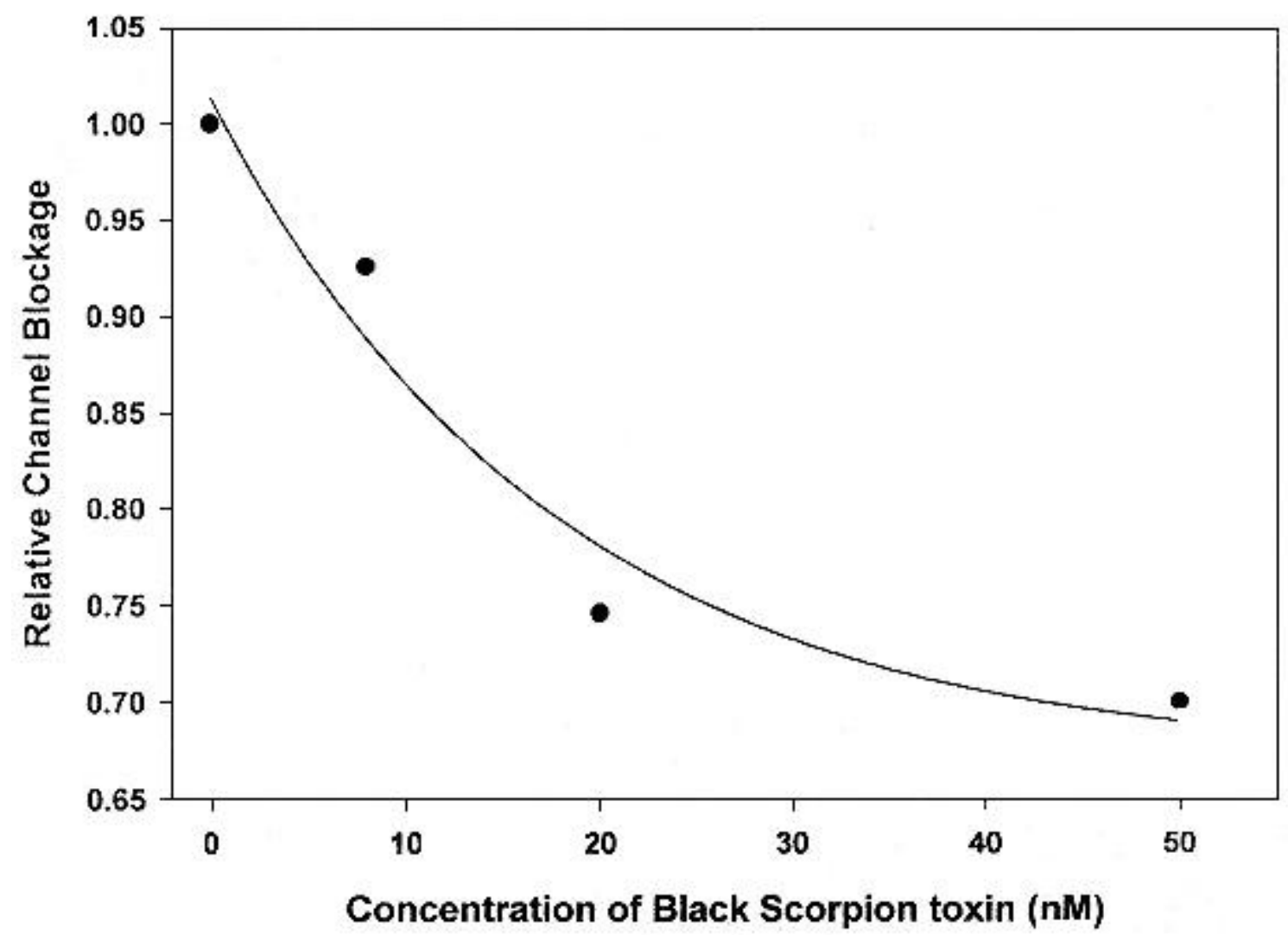

Figure 6e: Channel blockage as a function of the toxin concentration. 


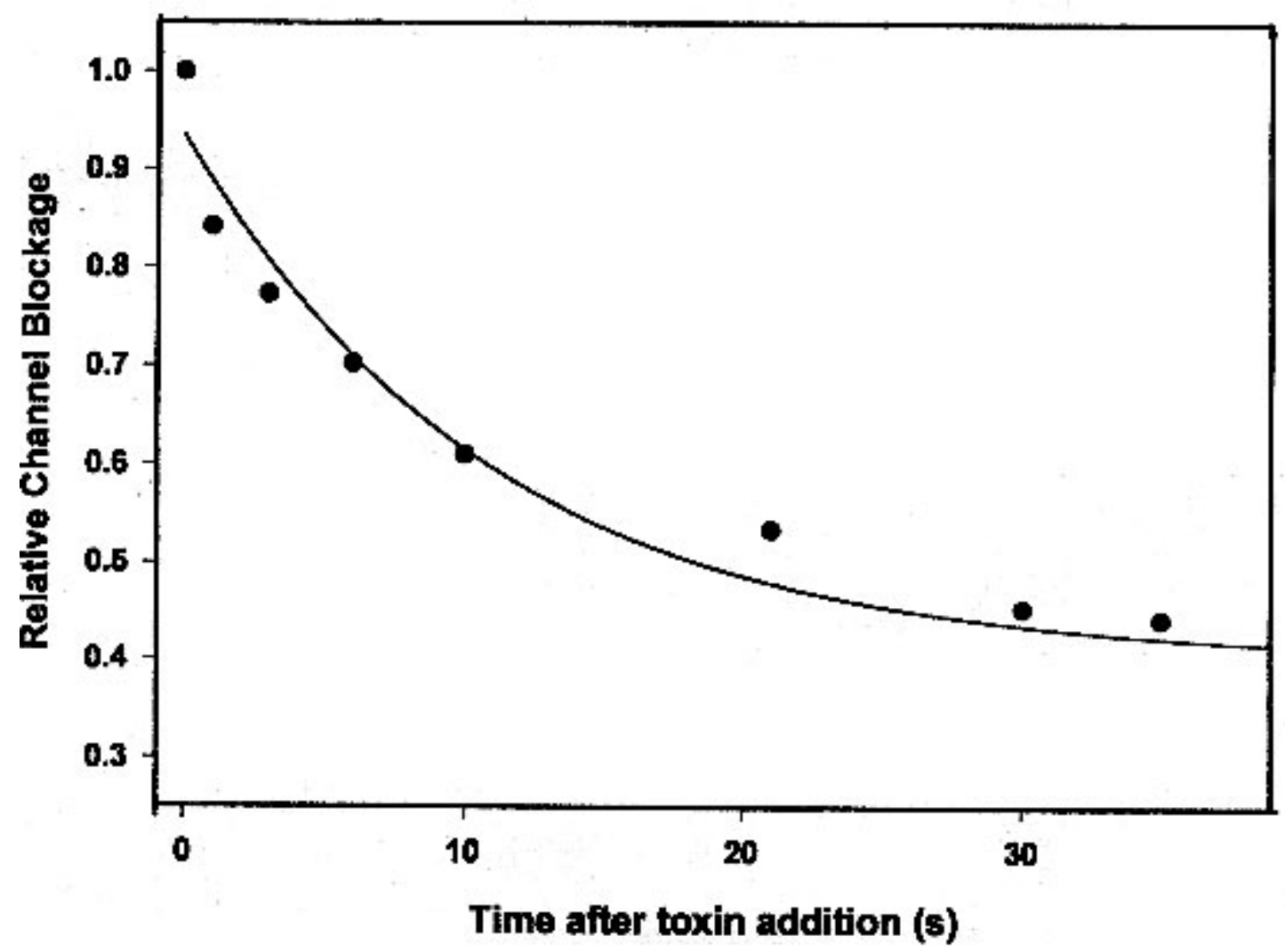

Figure 6f: Effect of the toxin at a given concentration at a single potential at different times. Time-dependence of the toxin action.

\section{DISCUSSION}

In the past, a large number of toxins have been isolated from various scorpion species $(19,8,18)$. The toxic action of the scorpion venom is probably due to a small amount of low molecular weight peptide toxins basic in nature (19).

In the present study we have isolated and characterized a novel potassium channel inhibitor from Palamneus gravimanus venom in a two-step procedure combining ion exchange and gel filtration chromatography. The molecular weight of the isolated toxin was about $4.5 \pm 1 \mathrm{kD}$, as assayed by SDS-PAGE, and had a LD $_{50}$ value of approximately $2 \mathrm{mg} / \mathrm{kg}$ body weight. Earlier researchers had isolated and purified toxins from different scorpion species. Galvez et al. (5) purified a 4.3 kD polypeptide, called "Ibtx", from the venom of Buthus tamulus. Romi-Lebrun et al. (17) purified three toxins ChTx from the Chinese scorpion Buthus martensi, with molecular mass ranges of $3800-4300 \mathrm{Da}$, and all of them were known to be potent inhibitors of voltage-gated potassium channels. Garcia et al. (6) purified a toxin from the venom of 
Leiurus quinquestriatus showing a molecular mass of about $4.1 \mathrm{kD}$, a potent inhibitor of shaker $\mathrm{K}^{+}$channel. Dhawan et al. (4) purified a peptide of about $3.5 \mathrm{kD}$ from Buthus tamulus (Indian red scorpion), known as BTK-2, which particularly inhibits the Kv1.1 channel. The data on toxins purification and their activities on $\mathrm{K}^{+}$channel in different scorpion species venoms suggested that the molecular mass of the toxin peptides ranged between 3.5 and $4.5 \mathrm{kD}$ and their activity was usually directed to blocking only Kv1.1 potassium channel without affecting Kv1.2 or Kv1.4, very closely related potassium channels. The most important application of such bioactive peptides is envisaged in neuropharmacological dissection of physiological processes and in drug design to provide templates leading to specific blocks. Further investigations are needed to determine the specific amino acid residues of the peptide toxin, which may be involved in the toxin and hKv1.1 channel interaction, and these toxins could probably be used to determine the architectural difference between the voltage-gated and the calcium activated channel pores.

In conclusion, we have purified and characterized a toxic peptide (toxin) from the venom of the Indian black scorpion Palamneus gravimanus. This toxin is a potent inhibitor of the hKv1.1 channel, which closely resembles the toxins Lq2 from Leiurus quinquestriatus and BTK-2 from Buthus tamulus, with respect to the molecular mass and action on voltage-gated potassium channels. The purified toxin is helpful in designing drug molecules and also as a molecular tool to explore the pore region of the voltage-gated Kv1.3 potassium channels (1). 


\section{REFERENCES}

1 AIYAR J., WITHKA JM., RIZZI JP., SINGLETON DH., ANDREWS GC., LIN W., BOYD J., HANSON DC., SIMON M., DETHLEFS B., LEE CL., HALL JE., GUTMAN GA., CHANDY KG. Topology of the pore-region of a $\mathrm{K}+$ channel revealed by the NMR-derived structures of scorpion toxins. Neuron, 1995, 15, 1169-81.

2 ANDREWS, P. Estimation of the molecular weights of proteins by Sephadex gelfiltration. Biochem. J. 1964, 91,222-33.

3 BAUMANN A., GRUPE A., ACKERMAN A., PONGS O. Structure of the voltagedependent potassium channel is highly conserved from Drosophila to vertebrate central nervous systems. EMBO J., 1988, 7, 2457-63.

4 DHAWAN RK., VARSHNEY A., MATHEW MK., LALA AK. BTK-2, a new inhibitor of the Kv1.1 potassium channel purified from Indian scorpion Buthus tamulus., FEBS Lett., 2003, 539, 7-13.

5 GALVEZ A., GIMENEZ-GALLEGOS G., REUBEN JP., ROY-CONTANCIN L., FEIGENBURN P., KACZOROWSKI GJ., GARCIA ML. Purification and characterization of a unique, potent peptidyl probe for high conductance calcium-activated potassium channel from venom of the scorpion Buthus tamulus. J. Biol. Chem., 1990, 265,11083-90.

6 GARCIA ML., GARCIA-CALVO M., HIDALGO P., LEE A., MACKINNON R. Purification and characterization of three inhibitors of voltage dependent $\mathrm{K}^{+}$ channels from Leiurus quinquestriatus Var. hebraeus venom. Biochemistry, 1994, 33, 6834-39.

7 GARCIA-CALVO M., LEONARD RJ., NOVICH J., STEVENS SP., SCHMALHOFER W., KACZOROWSKI GJ., GARCIA ML. Purification, characterization, and biosynthesis of margatoxin, a component of Centruroides margaritatus venom that selectively inhibits voltage-dependent potassium channels J. Bio. Chem., 1993, 268, $18866-74$.

8 GOMEZ MV., DAIL MEM., DINIZ CR. Effect of scorpion venom Tityustoxin on the release of acetylecholine from incubated slices of rat brain. J. Neurochem. , 1973, 20, 1051-61.

9 HARVEY AL. Neuropharmacology of potassium ion channels. Med. Res. Rev. 1993, 13, 81-104. 
10 LAEMMLI UK. Cleavage of structural proteins during the assembly of the head of bacteriophage $_{4}$. Nature, 1970, 227,680-5.

11 LIMAN ER., TYTGAT J., HESS P. Subunit stoichiometry of a mammalian K+ channel determined by construction of multimeric cDNAs. Neuron, 1992, 9, 861-71.

12 LOWRY OH., ROSENBROUGH NJ., FARR AL., RANDALL RJ. Protein measurement with the folin phenol reagent. J. Biol. Chem., 1951,193, 265-75.

13 MACKINNON R., REINHART PH., WHITE MM. Charybdotoxin block of Shaker $\mathrm{K}+$ channels suggests that different types of $\mathrm{K}+$ channels share common structural features. Neuron, 1988,1, 997-1001.

14 MARTIN- EAUCLAIRE MF., CAURAUD F. In: CHANG LW., DYER RS. Eds. Hand book of Neurotoxicology. Marcel Dekker Inc. : New York, 1995: 683-716.

15 RAMACHANDRAN LK., AGARWAL OP., ACHYUTHAN KE., CHAUDHARY L., VEDASIROMANY JR., GANGULY DK. Fractionation and biological activities of venoms of the Indian scorpions Buthus tamulus and Heterometrus bengalensis. Indian J. Biochem. Biophys., 1986, 23, 355-58.

16 REED LJ., MUENCH HA. A simple method for the estimating fifty percent endpoints. Am. J. Hyg. 1938, 37, 493-7.

17 ROMI- LEBRUN R., LEBRUN B., MARTIN-EAUCLAIRE MF., ISHIGURO M., ESCOUBUS P., WU FQ., HISADA M., PONGS O., NAKAJIMA T. Purification, characterization and synthesis of three novel toxins from the Chinese scorpion Buthus martensi, which act on $\mathrm{K}^{+}$channels. Biochemistry, 1997, 36, 13473-82.

18 TIKADER BK., BASTWADE DB. The fauna of Indian scorpion, Scorpionida. Arachnida. Zoo. Surv. India, 1983, 3, 1-686.

19 ZLOTKIN E., SHULOV AS. Recent studies on the mode of action of scorpion neurotoxins. A review. Toxicon,1969, 7, 217-21. 